\title{
INCIDENTALLY DETECTED RENAL PELVIS SQUAMOUS CELL CARCINOMA IN NON FUNCTIONING KIDNEY
}

\author{
Rakesh Kumar Yadav¹, R. K. Kajla², P. S. Rajput ${ }^{3}$, S. P. Chouhan4, Narender Kumar ${ }^{5}$
}

\section{HOW TO CITE THIS ARTICLE:}

Rakesh Kumar Yadav, R. K. Kajla, P. S. Rajput, S. P. Chouhan, Narender Kumar. "Incidentally Detected Renal Pelvis Squamous Cell Carcinoma in Non Functioning Kidney". Journal of Evolution of Medical and Dental Sciences 2014; Vol. 3, Issue 19, May 12; Page: 5272-5275, DOI: 10.14260/jemds/2014/2586

ABSTRACT: Primary renal squamous cell carcinoma is a very rare clinical entity. Very few of such cases have been reported in world literature. Diverse etiological factors, non-specific clinical presentation and radiological findings of this tumor lead to difficulty in diagnosis. The diagnosis is established only after the histological examination of the resected specimen. This case which has been reported here was a case of primary renal squamous cell carcinoma in right kidney with perinephric abscess.

KEYWORDS: perinephric abscess, renal stone, non-functioning kidney, squamous cell carcinoma.

INTRODUCTION: Primary urothelial malignancies of renal collection system are rare and accounts for 4-5 \% of all urothelial tumours. ${ }^{1}$ Incidence of primary squamous cell carcinoma of kidney, among renal transitional cell carcinoma and adenocarcinomas is $0.5 \%$ to $8 \%{ }^{2}$

Squamous cell carcinoma of renal origin is more frequently seen in lower urinary tract and bladder and urethra, it is rarely reported in upper urinary tract. These squamous cell carcinomas of renal origin are highly aggressive and at the time of diagnosis they are present in advanced stage with moderate to poor differentiated histology. ${ }^{3}$

Most of the patients presents with history of chronic urolithiasis, renal infection or analgesic abuse. Diagnostic findings of solid masses, hydronephrosis and calcifications are common, but these are non-specific radiological findings. The diagnosis is established only after the histological examination of the resected specimen. An early metastatic spread is common and the prognosis is poor, due to diagnosis of the carcinoma in late stages. ${ }^{4}$

Surgery is the mainstay treatment of SCC of renal pelvis, adjuvant chemotherapy has marginal benefit. The case which has been reported here had squamous cell carcinoma of the renal pelvis with perinephric abscess, renal stone and non-functioning kidney.

CASE REPORT: A 30 year old male, farmer by occupation, presented with history of intermittent pain in right side of abdomen for one month. There was also a history of on and off low grade fever. Clinical examination revealed right sided abdomen fullness and tenderness. The routine lab investigations were performed; Hemoglobin was 10.2 gm. \% and peripheral blood smear shows neutrophillic leukocytosis. TLC $=20,000$ per cubic $\mathrm{mm}$. The ESR was $40 \mathrm{~mm}$ after $1^{\text {st }}$ hour. Urinalysis revealed pyuria.

USG guided percutaneous drainage done using pig tail catheter and patient condition improved; after five days drain removed and patient was discharged, but patient lost follow-up for one year and again came with right flank pain. Then renal scintigraphy with isotope 99mTC-DT showed non-functioning kidney (right side). Total nephrectomy (right kidney) was performed and 
the specimen was sent for histopathological examination that showed features of squamous cell carcinoma.

DISCUSSION: Primary malignancies of renal pelvis are relatively rare and contribute 8-14\% of all renal malignancies. ${ }^{5}$ Transitional cell carcinoma; adenocarcinoma and squamous cell carcinoma are variants of carcinoma of renal urothelium, among these squamous cell carcinoma accounts for 0.5 to $8 \% .^{2}$

Presence of squamous metaplasia of adjacent urothelium suggests its origin due to metaplastic changes in the urothelium. Various etiological factors have been reported foe metaplasia and subsequent carcinoma changes; are long standing stag horn calculi and the infections, exogenous and endogenous chemicals, vitamin A deficiency, hormonal imbalance, schistosomiasis and smoking. ${ }^{6}$ $94 \%$ of the renal squamous cell carcinomas usually present in an advanced stage at the time of the initial diagnosis. ${ }^{7}$ A median 5-11 months survival has been reported in a previous case series.

Hypocalcaemia, leukocytosis and thrombocytosis have been reported to be a part of the paraneoplastic syndromes in renal squamous cell carcinoma. ${ }^{8}$

Squamous cell carcinoma of the renal collective system is a rare malignancy with poor prognosis. Surgery is the mainstay treatment for squamous cell carcinoma of renal pelvis, nephrectomy with or without ureterectomy is performed in these cases. Nephrectomy is necessary to establish a histological diagnosis even in the face of metastatic disease. For control of symptoms such as - pain, fever and hematuria, or to eliminate the source of the infection a systemic chemotherapy can be instituted. Chemotherapy and palliative radiotherapy has been advocated for the control of the local symptoms in metastatic disease, but they have failed to show any survival benefit. ${ }^{2}$

Biopsies from the renal pelvis or the calyceal wall should be considered in case of long standing large renal calculi, especially in cases of stag horn calculus. Such patients are susceptible for harboring occult or overt malignancy along with the renal stone disease. ${ }^{9}$ Diagnosis of the renal SCC is difficult as characteristics features usually not associated with renal SCC, added by imaging techniques which reveals only calculi and hydronephrosis. Therefore initial diagnosis of SCC is mostly based on histological analysis as was seen in present case.

CONCLUSION: The diagnosis of squamous cell carcinoma of the kidney is difficult on clinical grounds; it is a diagnostic challenge. Radiological investigations can only give information regarding hydronephrosis, calculus or the presence of any growth (tumor) but, they may not give an accurate diagnosis. A histological examination helps in deriving an accurate diagnosis, as was seen in the present case. The present article emphasizes the importance of combined clinical, surgical and histopathological approach. The possibility of a malignancy should always be kept in mind in all the complicated cases and a histopathological examination should be performed in all the cases. Early detection and treatment will be beneficial to increase the survival of the patient.

\section{REFERENCES:}

1. Murphy DM, Zincke H, Furlow WH. Primary grade 1 transitional cell carcinoma of renal pelvis and ureter. J Urol 1980; 123: 629-31.

2. Blacher EJ, Johnson DE, Abdui-Karim FW. Squamous cell carcinomas of renal pelvis. Urology 1985; 25: 124-6. 


\section{CASE REPORT}

3. Flanigen RC, Urothelial Tumours of the Upper Urinary tract. In: Alan J. Wein, editor. CampbellWalsh Urology, 9th ed. China: Saunders Elsevier; 2007; 1638-52.

4. Holmang S, Lele SM, Johansson SL. Squamous cell carcinoma of the renal pelvis and the ureter: incidence, symptoms, treatment and outcome. J Urol 2007; 178: 51-6.

5. Tyagi N, Sharma S, Tyagi SP, Maheshwari V, Nath P, Ashraf SM et al. A histopmorphologic and an ultrastructural study of the malignant tumors of the renal pelvis. J Postgrad Med 1993; 39: 197201.

6. Mathur SK, Rana P, Singh S, Goyal V, Sangwan M. An incidentally detected squamous cell carcinoma in a non-functioning kidney, presenting as a multi-cystic mass. Jour Surg Case reports 2011; 9:1-4.

7. Bostrom PJ, Soloway MS. Upper urinary tract cancer-challenges for the urologist. J Urol 2007; 178:12-13.

8. Er O, Coskun HS, Altinbas M, Akgun H, Cetin M, Eser B et al. Rapidly relapsing squamous cell carcinoma of the renal pelvis associated with paraneoplastic syndromes of leukocytosis, thrombocytosis and hypercalcemia. Urol Int 2001; 67: 175-7.

9. Singh V, Sinha RJ, Sankhwar SN, Mehrotra B, Ahmed N. Squamous cell carcinoma of the kidney rarity redefined: ease series with review of literature. J Canc Sci Ther 2010; 2: 82-5.

Fig. 1: showing renal tubules, sheets of squamous cells and areas of keratin pearls. Cells have hyperchromatic nuclei with increased N: C ratio.

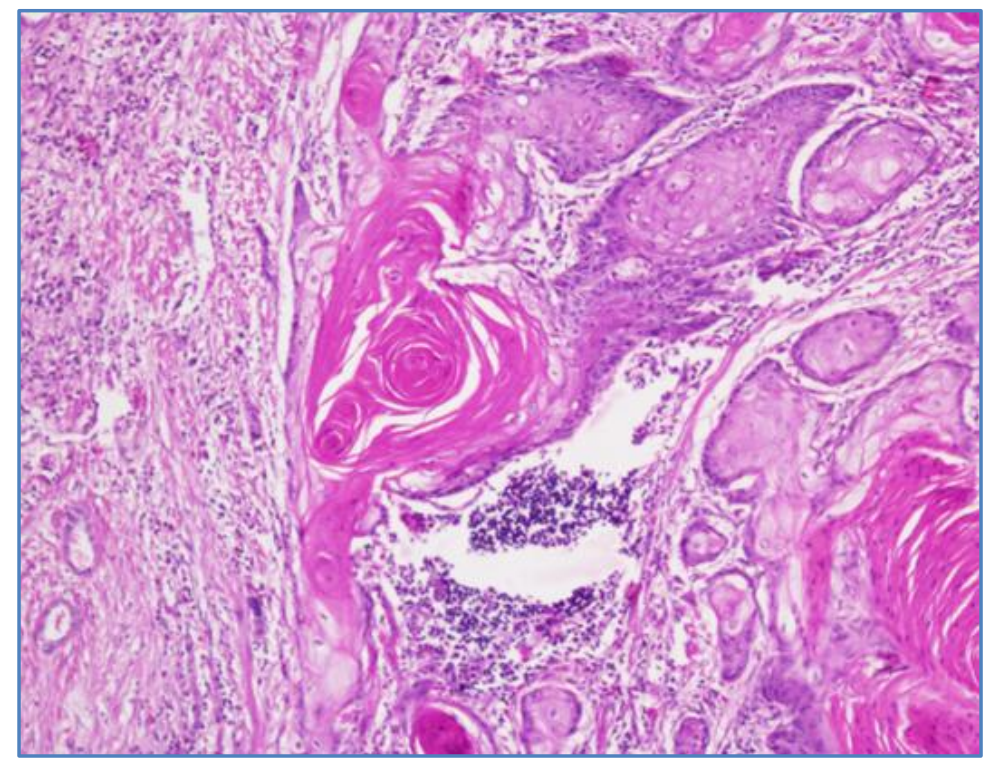

Figure 1 


\section{CASE REPORT}

Fig. 2: showing areas of squamous pearls and squamous cells. Cells show features of malignancy like increased N: C ratio, anisonucleosis, and hyperchromatism. Giant cells are also seen.

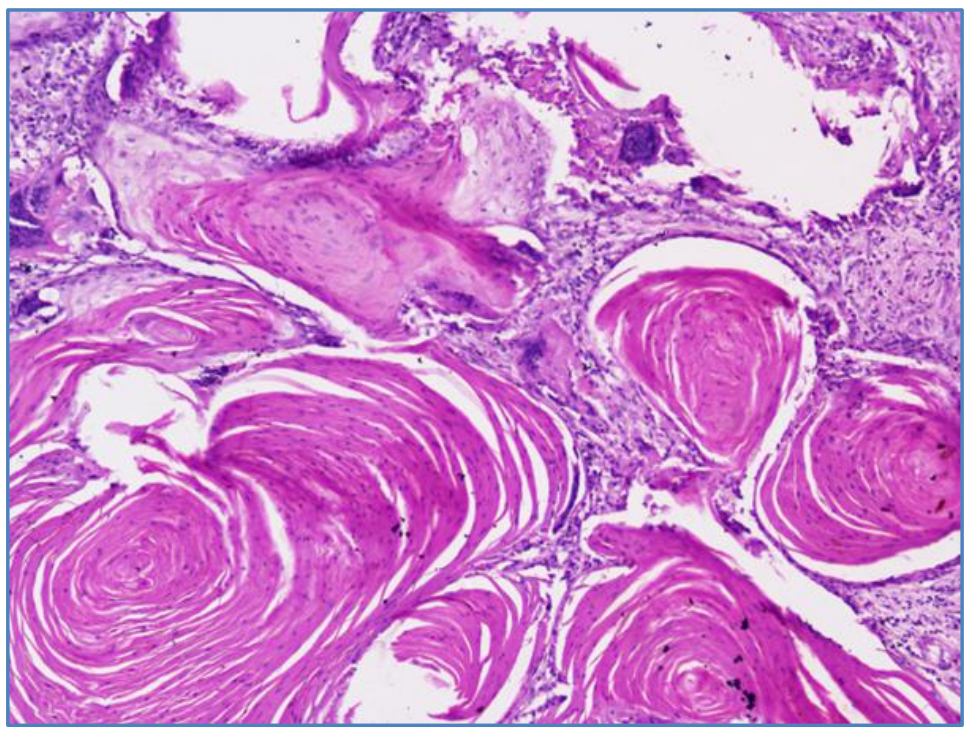

Figure 2

\section{AUTHORS:}

1. Rakesh Kumar Yadav

2. R. K. Kajla

3. P.S. Rajput

4. S. P. Chouhan

5. Narender Kumar

\section{PARTICULARS OF CONTRIBUTORS:}

1. Senior Resident, Department of General Surgery, Sardar Patel Medical College, Bikaner, India.

2. Associate Professor, Department of General Surgery, Sardar Patel Medical College, Bikaner, India.

3. Medical Officer, Department of General Surgery, Sardar Patel Medical College, Bikaner, India.

4. Professor, Department of General Surgery, Sardar Patel Medical College, Bikaner, India.
5. Intern, Department of General Surgery, Sardar Patel Medical College, Bikaner, India.

\section{NAME ADDRESS EMAIL ID OF THE CORRESPONDING AUTHOR:}

Dr. Rakesh Kumar Yadav,

Department of General Surgery,

Sardar Patel Medical College,

Bikaner, India.

Email: dr.rakeshyadav11@gmail.com

Date of Submission: 14/04/2014.

Date of Peer Review: 15/04/2014.

Date of Acceptance: 26/04/2014.

Date of Publishing: 12/05/2014. 